\title{
Lipid peroxide, glutathione and glutathione-dependent enzyme (GST) in mixed zooplankton from the North- West Coast of India: Implication for the use of environmental monitoring
}

\author{
Vijayakumar Rathod and Patil Balkrishna A. \\ National Institute of Oceanography (CSIR) Dona Paula, Goa-403004, India. \\ Accepted 21 March, 2011
}

\begin{abstract}
This work deals with an experiment on mixed zooplanktonic organisms collected from the shore water of Diu coast. The study analyzed and measured lipid peroxidation (LPX), as a marker of oxidative stress and glutathione-s-transferase (GST) activity, as a marker of organic pollution. Both LPX and GST activities were highest at the stations close to the shore and marginally decreased along with transect. The reduced glutathione (GSH) levels were highly variable. The results were discussed in relation to the biomarker application of mixed zooplankton, lipid peroxidation (LPX), glutathione-S-transferase (GST) and reduced glutathione (GSH). The results indicated that, the three potential markers (LPX, GST and GSH), could be used as a measure for bio-monitoring the costal ecosystem using mixed zooplankton as suitable organisms.
\end{abstract}

Key words: Zooplankton, lipid peroxidation, glutathione-S-transferase, reduced glutathione.

\section{INTRODUCTION}

Marine environments are subjected to several forms of disturbances related to anthropogenic activities such as shipbuilding, transport, oil refinery spill, industrial and urban effluents, dredging and dumping of sediments, often extending their influence through diffusion of pollutants. The water born pollutants which generate reactive oxygen species (ROS) are the source of toxicity for aquatic organisms living in the polluted environment and practically responsible for disruption of physiological functions (Livingstone, 2001).

${ }^{*}$ Corresponding author. E-mail: rathod@nio.org.

Abbreviations: LPX, Lipid peroxidation; GST, glutathione-Stransferase; GSH, reduced glutathione; ROS, reactive oxygen species; SOD, superoxide dismutase; GPx's, peroxidations; SH, cystin, TBA, thiobarbituric acid; SDS; sodium dodecyl sulfate; TBARS, thiobarbituric acid reactive substances; BHT, butylated hydroxyl toluene; $\mathbf{P A H}$, petroleum aromatic hydrocarbon; DPPH, 2-2-Diphenyl-1-picrylhydrazyl; CDNB, 1chloro-2, 4-dinitrobenzene.
ROS such as superoxide radical $\left(\mathrm{O}_{2} \bullet\right)$, hydroxyl radical $(\mathrm{OH} \bullet)$ and hydrogen peroxide $\left(\mathrm{H}_{2} \mathrm{O}_{2} \bullet\right)$, etc., are highly reactive compounds, which if not neutralized efficiently, will attack almost all bio-molecules of cells including proteins and DNA. Membrane lipids are more susceptible to their attack generating lipid peroxidation (Elstner, 1991). To protect themselves from these highly reactive compounds, cells have their own interdependent antioxidative defense system, composed of protective proteins that remove the ROS/RNS. These chemical radicals are normally metabolized by the enzymatic antioxidants, such as superoxidants and superoxide dismutase (SOD), that converts superoxide anion $\left(\mathrm{O}_{2} \bullet-\right)$ to $\mathrm{H}_{2} \mathrm{O}_{2}$ in all aerobic organisms. Catalase degrades $\mathrm{H}_{2} \mathrm{O}_{2}$ to water and oxygen, and GPx detoxifies both $\mathrm{H}_{2} \mathrm{O}_{2}$ and hydro peroxides $(\mathrm{ROOH})$, using reduced glutathione (GSH) as a cofactor. Intracellular homeostasis cycling is regulated by antioxidants, mainly by thiol-containing molecules such as GSH. Glutathione reductase (GR) has important role in maintaining the intracellular status of GSH. Glutathione S-transferase (GST) catalyzes conjugation reaction with $\mathrm{GSH}$. Apart from this, cells possess 
some other antioxidant defense mechanism to neutralize the effect of toxic compounds. Metallothionein (MT), has a high content of cystein (SH) group protein, which detoxifies heavy metals (Halliwell et al., 1986a; RomeroIsart et al., 2002).

Zooplanktons are small heterotrophic animals inhabiting almost every type of aquatic environment. Numerous studies have demonstrated the suitability of zooplankton for biomarker study (Fossi et al., 2001a; Petres et al., 2001b). Marine zooplanktons have relatively high lipid reserves and can accumulate hydrophobic compounds directly from the sea or by ingestion of contaminated prey. Several studies have focused on the distribution of the conservative contaminants in zooplanktons (Harding, 1986; Shailaja et al., 1991). Kureishy et al. (1978) and Kanan and Sen Gupta (1987) also reported the values of total DDT in zooplankton from the Arabian Sea as 0.3 to $3.2 \mu \mathrm{g} / \mathrm{g}$, but very little has been concluded about their toxic effects in marine organisms, especially on zooplankton. Zooplanktons are close to the base of the marine food web and therefore, can play a vital role in transfer of pollutants through several tropical levels. Ecotoxicological risks to zooplankton can be used as an early warning signal of risk to the health of the marine ecosystem. In this study, the potential use of certain biomarkers in mixed zooplankton was investigated. Attempts were made to measure the level of LPX, GST activity and GSH level in mixed zooplankton.

\section{MATERIALS AND METHODS}

Zooplankton samples were collected from 12 different stations along and off Diu coast on the 5th and 7th of October 2009 covering the geographical limits of latitude $20^{\circ} 39^{\prime} 53.3$ to $20^{\circ} 42^{\prime} 02.3 \mathrm{~N}$ and longitude $71^{\circ} 00^{\prime} 26.0$ to $71^{\circ} 04^{\prime} 59.7 \mathrm{E}$. (Figure 1). For this purpose, horizontal hauls were taken using Heron Traton net of mesh size $200 \mu \mathrm{m}$. A trawler was used to operate the net (Tow speed at $1.5 \mathrm{knot}$, haul time $5 \mathrm{~min}$ ). The total water filtered was computed with the help of the current speed, mouth area of the sampling net and towing time. $50 \%$ of the collected sample was preserved in $5 \%$ neutralized formaldehyde for identification and quantitative analysis and the remaining $50 \%$ samples were filtered, washed in distilled water and cryopreserved in liquid nitrogen cans for biochemical estimation.

\section{TBARS assay}

The whole animals were processed and were assayed according to the method of Ohkawa et al. (1979) with minor modifications. In brief, the reaction mixture that contained approximately $1 \mathrm{mg}$ of protein, $1.5 \mathrm{ml}$ of $0.8 \%$ aqueous solution of thiobarbituric acid (TBA), $1.5 \mathrm{ml}$ of $20 \%$ acetic acid $\left(\mathrm{CH}_{3} \mathrm{COOH}\right)(\mathrm{pH} 3.5)$ with $\mathrm{NaOH}$, $0.2 \mathrm{ml}$ of $(8.1 \%)$ sodium dodecyl sulfate (SDS), $0.2 \mathrm{ml}$ of double distilled water and $0.1 \mathrm{ml}$ of $(0.76 \%)$ butylated hydroxyl toluene (BHT) was heated at $95^{\circ} \mathrm{C}$ for $60 \mathrm{~min}$, then cooled to room temperature and centrifuged at $2000 \times g$ for $10 \mathrm{~min}$. The absorbance of the supernatant was read at $532 \mathrm{~nm}$. The amount of thiobarbituric acid reactive substances (TBARS) formed was calculated by using an extinction coefficient of $1.56 \times 10^{5} \mathrm{M}^{-1} \mathrm{~cm}^{1}$ and expressed as nmol TBARS performing protein.

\section{Measurement of GST activity}

The mixed zooplankton was carefully surface dried with filter paper, thoroughly washed with phosphate buffer $(\mathrm{pH} 7.4)$ and homogenized with $50 \mathrm{mM}$ phosphate buffer $(\mathrm{pH} 7.4)$ containing 1 $\mathrm{mm}$ EDTA, $1 \mathrm{~mm}$ DTT, $0.15 \mathrm{M} \mathrm{KCL}$ and $0.01 \%$ PMSF. Homogenization was carried out at $4^{\circ} \mathrm{C}$ using 12 to 15 strokes of a motor driven Teflon Potter homogenizer and was centrifuged at 10,000 $\times g$. The supernatant was taken for enzyme assay. The enzyme GST was measured at $340 \mathrm{~nm}$ according to Habig et al. (1974) using 0.3 $\mathrm{mM}$ CDNB as substrate.

\section{Measurement of reduced glutathione (GSH)}

A crude homogenate (20\%) was prepared with $5 \%$ trichloro-acetic acid (TCA) and was centrifuged at $2000 \times g$ for $10 \mathrm{~min}$. The deproteinised supernatant was used for the assay of GSH using 0.6 mM DTNB in $0.1 \mathrm{M}$ phosphate buffer $(\mathrm{pH} \mathrm{8.0)}$ ) and the formation of thiol anion was measured at $412 \mathrm{~nm}$.

\section{Estimation of proteins}

Protein content was estimated by the Folin-phenol reaction as described by Lowry et al. using bovine serum albumin (BSA) as a standard.

\section{RESULTS}

In this investigation, 17 different zooplanktonic groups were observed during the study period at 12 stations, where Copepoda contributed almost $97 \%$ of the total zooplankton density followed by Doliolids (0.95\%), Brachyuran zoea $(0.83 \%)$, Eupliausiid $(0.25 \%)$, and Chaetognatha (0.23\%). Hydromedusae $(0.16 \%)$, amphipoda $(0.15 \%)$ and salpa $(0.13 \%)$ contributed a little higher share in the total population while other groups like Lucifer $(0.01 \%)$, bivalve $(0.00 \%)$, fish eggs $(0.02 \%)$ and polychaeta $(0.00 \%)$ were very rare in their occurrence. A total number of 4 orders were recorded belonging to the group Copepoda: Calanoida, Cyclopoida, Harpacticoida and Mostrilloida. Calanida was the dominant order among the copepods accounting for $96.65 \%$ of the total Copepod density followed by Cyclopoida (3.28\%), Harpacticoida $(0.07 \%)$ and Mostrilloida (0.004\%).

The lipid peroxidation (LPX) was determined in subcellular fraction of this mixed zooplankton. The highest LPX level was observed in stations 2, 3, 5, 7, 8, 9, 10, 11 and 12 (Figure 2a). Glutathione-S-transferase (GST) and reduced glutathione (GSH) levels was reported in greater variation. The GST activities were indicated to be in stations 3, 10, 11 and 12 (Figure 2b). The non-enzymatic antioxidant reduced glutathione contents were high in stations 2, 3, 5, 7, 8, 10, 11 and 12 (Figure 2c).

\section{DISCUSSION}

The aim of these studies was to evaluate the potential 


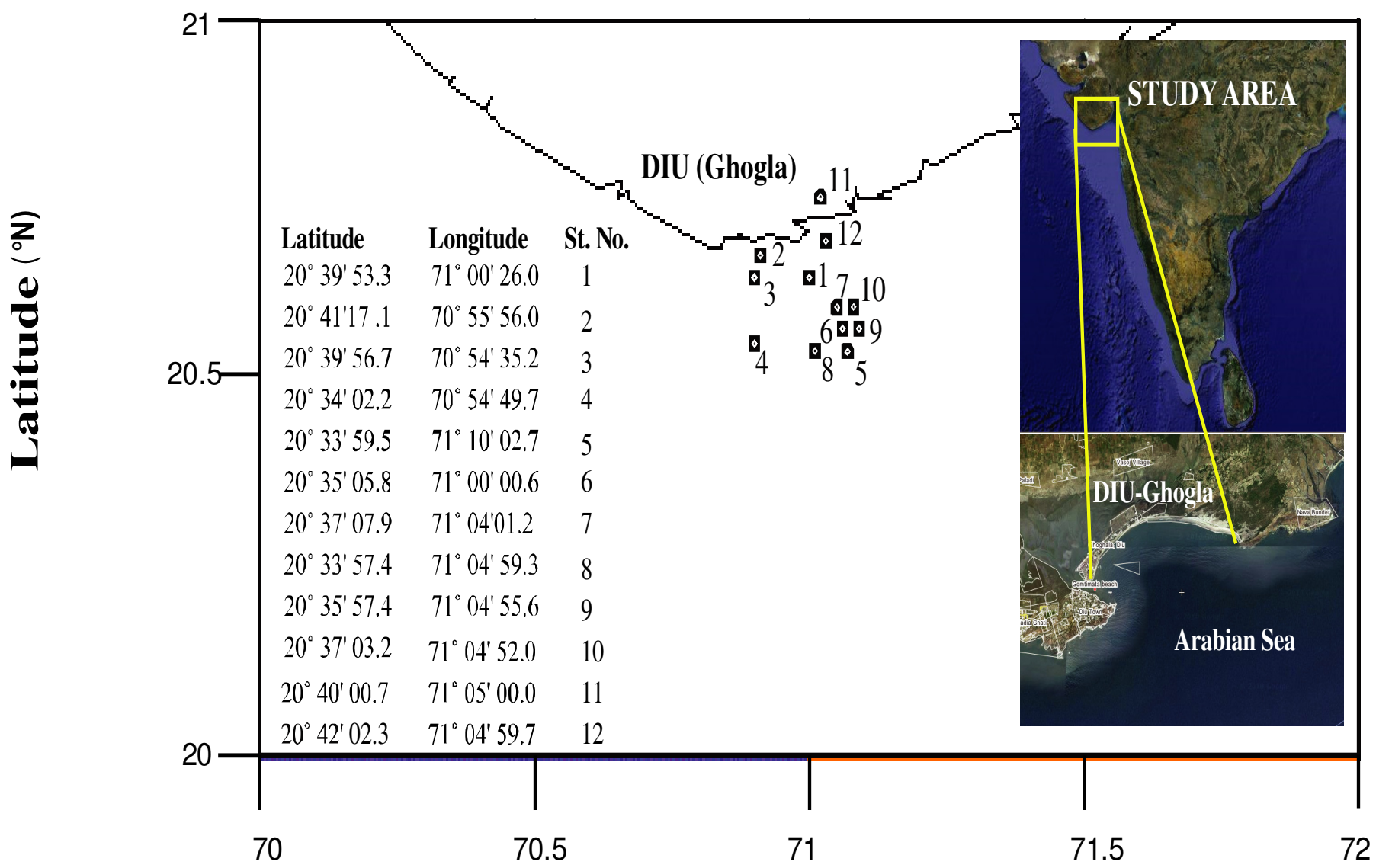

\section{Longitude ( $\left.{ }^{\circ} \mathrm{E}\right)$}

Figure 1. Sampling site of zooplankton collection near the shore water of Diu Island.

use of certain biomarkers (LPX, GST and GSH) in mixed zooplanktonic organisms. LPX, GST and GSH levels were measured in the sub-cellular fraction of mixed zooplankton from the Arabian sea. Attack by molecular oxygen produces lipid peroxynulical that can abstract a hydrogen atom from an adjacent lipid to form a lipid hydroperoxide. The LPX process affects membrane fluidity and integrity of biomolecules associated with membrane and can be quantified by measuring TBARS assay. The formation of TBARS is commonly used as a marker of biomembrane lipid peroxidation, which is an indicator of oxidative stress (Oakes et al., 2003). Therefore, lipid peroxidation (LPX) has been taken as an index of oxidative stress. The highest LPX level was observed at stations 2, 3, 5, 7, 8, 9 10, 11 and 12 (Figure 2a), closer to the outflow of the river Ghogla (Figure 1). Since TBARS is primarily an outcome of generation of free radicals, it was suggested that this organism is faced an oxidative challenge. This result agrees with results obtained with mussels, when exposed to copper $(\mathrm{Cu})$, aluminum $(\mathrm{Al})$, lead $(\mathrm{Pb})$, cadmium $(\mathrm{Cd})$ and in field study
(Viarengo et al., 1990; Torres et al., 2002). The laboratory early findings suggested that, exposure of mercury $(\mathrm{Hg}), \mathrm{WSF}$ of petrol and diesel, naphthalene and pyrene to Perna viridis generated LPX.

GSH is the most abundant intracellular thiol and through its antioxidant properties, it is able to protect cells from ROS formed during normal mitochondrial respiration and metabolism of foreign chemicals (Hammond et al., 2004). Glutathione exerts its antioxidant function by reaction with superoxide radical $\left(\mathrm{O}_{2}{ }^{\circ}\right)$, peroxy radical and singlet oxygen $\left({ }^{1} \mathrm{O}_{2}\right)$ followed by the formation of oxidized glutathione and other sulfides. A decrease in tissue concentration (Figure 2c) of available GSH may be due to increased consumption of GSH via GST or it may have directly reacted with ROS, in turn leading to alteration in the redox balance. Decreased GSH level was found in mussel exposed to copper (Cu). De Giulio et al. (1995) suggested that, trace metals can bind to GSH and thereby, limit its availability to counteract lipid peroxidation and DNA damage. Further, when GSH values were plotted versus LPX, it showed a correlation $(r=-0.596, p<0.05)$ 

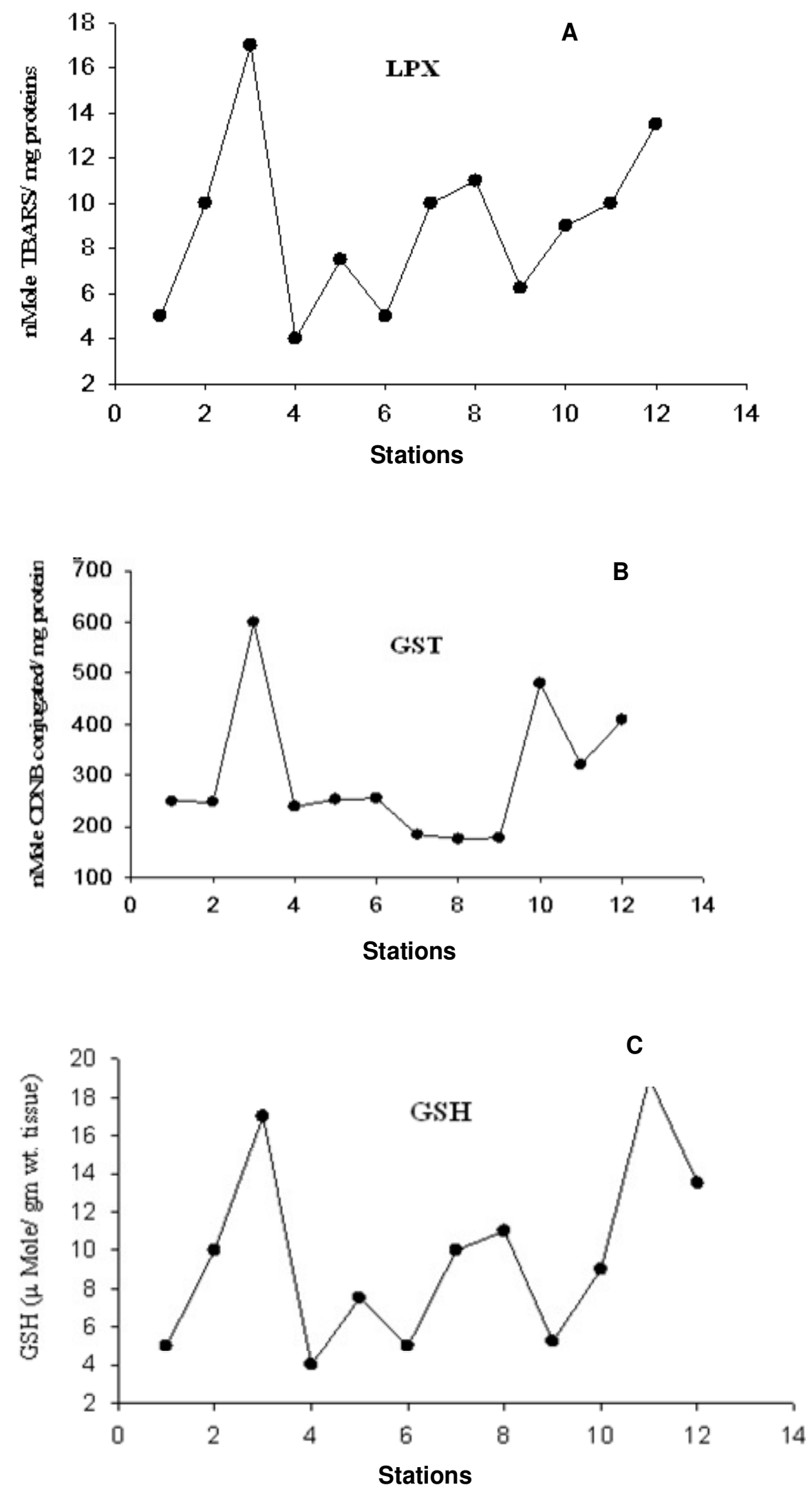

Figure 2. (A), Lipid peroxidation level (nmol TBARS/mg protein); (B), glutathione Stransferase (nmole CDNB formed/mg proteins); $(\mathrm{C})$, reduced glutathione level ( $\mu \mathrm{mole} / \mathrm{mg}$ weight tissue). 

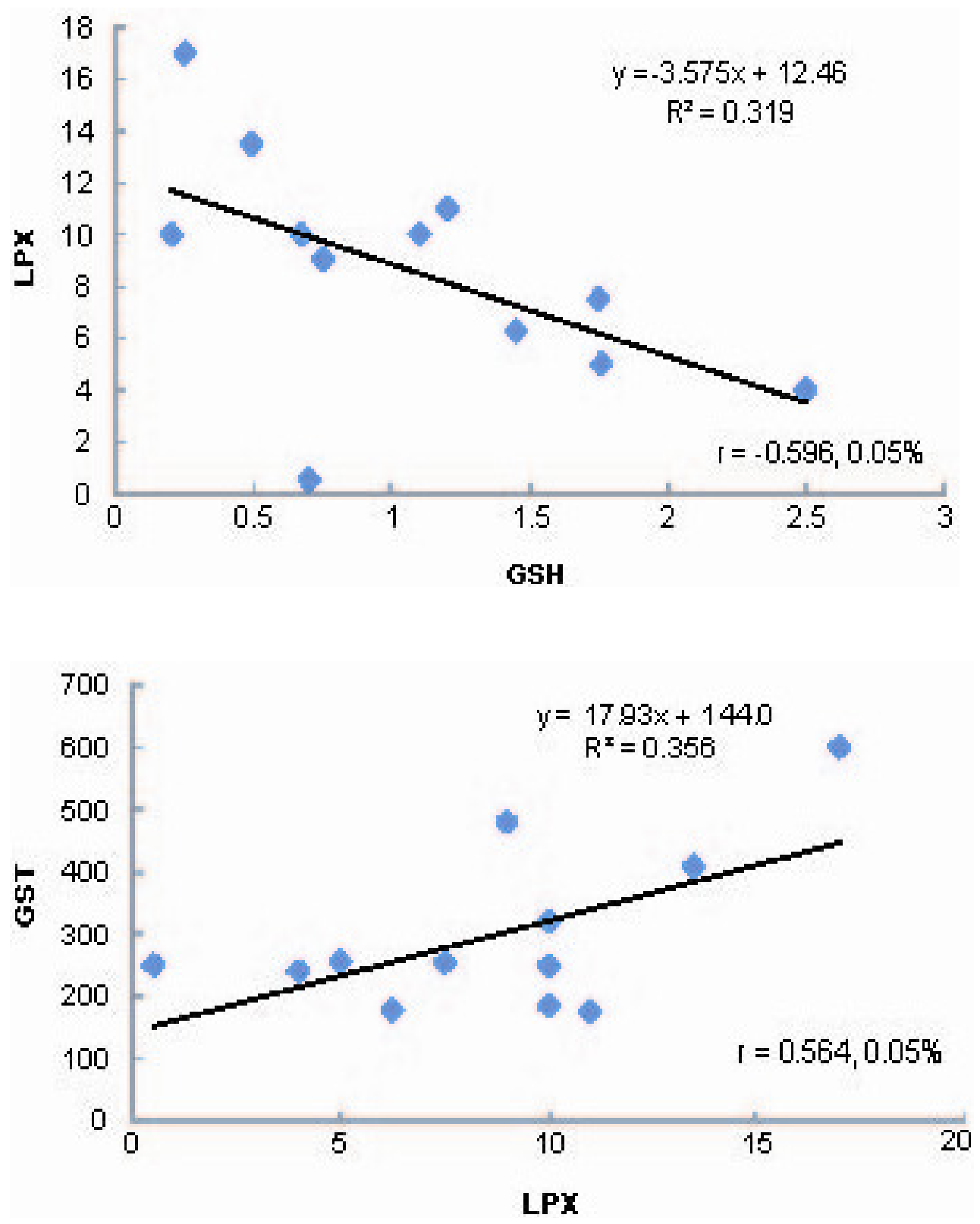

Figure 3. Correlation between GHS (nmole/g/weight tissue) and LPX (nmole TBARS/mg proteins); (B) correlation between GST (nMole CDNB conjugated formed/min/mg proteins) and LPX (nMole TBARS/mg protein) of mixed Zooplankton.

(Figure 3a). This suggests that GSH might play an important role in protecting the organisms from ROS.

Potential source of contaminant mediated ROS production by marine organisms include interactions with metals, petroleum aromatic hydrocarbon $(\mathrm{PAH})$ and other organic chemicals such as nitroaromatics (Lemaire et al., 1994). The study also focused on the phase II GST enzymes at different stations. GSTs are a multigen family of enzymes (isoforms) grouped into seven classes: alpha, $\mathrm{mu}$, pi, theta, sigma, zeta and omega (Lenartova et al., 1997a; Mennervick, 1985b). The enzyme catalyzes the conjugation of a large variety of compounds bearing an electrophillic site, with reduced glutathione (Edwards et al., 2000). GST activity varies in different stations (Figure 2b). Interestingly, a positive correlation was obtained with LPX level (Figure 3b). Edwards et al. (2000) reported that, glutathione transferase play an important role in the detoxification of ROS in the cells and protecting the lipids from peroxidation. The induction of GST activity of mussels in field study, by toxicant was done by several authors in the organisms (Prakash, 1995; Torres, 2002; Canesi, 1999; Bainy, 2000; Strmac and Braunbeck, 2002; Lau, 2003). The increase in GST activity may be a strategy to prepare for oxidative stress in an effort to defend cells 
Table 1. Measurement of LPX, GST and GSH per gram proteins by TBARS and CNDB methods.

\begin{tabular}{lcccccccccccc}
\hline Station & $\mathbf{1}$ & $\mathbf{2}$ & $\mathbf{3}$ & $\mathbf{4}$ & $\mathbf{5}$ & $\mathbf{6}$ & $\mathbf{7}$ & $\mathbf{8}$ & $\mathbf{9}$ & $\mathbf{1 0}$ & $\mathbf{1 1}$ & $\mathbf{1 2}$ \\
\hline TBARS/mg proteins & 5 & 10 & 17 & 4 & 7.5 & 5 & 10 & 11 & 6.25 & 9 & 10 & 13.5 \\
nMole CNDB conjugated/ proteins & 249 & 258 & 600 & 239 & 253 & 255 & 184 & 175 & 177 & 480 & 320 & 409 \\
GSH $(\mu \mathrm{M} / \mathrm{g}$ weight of tissues $)$ & 0.7 & 0.2 & 0.25 & 2.5 & 1.74 & 1.77 & 1.1 & 1.2 & 1.45 & 0.75 & 0.67 & 0.49 \\
\hline
\end{tabular}

against oxidative damage $(r=0.56, p<0.05)$ (Figure $3 b)$. From the result, it can be suggested that, the zooplanktons more effectively use the glutathione metabolism pathway as an adaptive response against ROS generated pollutants.

\section{Conclusions}

In this study, variations of LPX, GSH and GST activity in the mixed zooplankton was reported. An increase in LPX and GST activity in mixed zooplankton collected in the near shore area was shown which marginally decreased until it levels off. This study permits a better characterization of the impact of pollution on marine organisms taken together. The present results indicate that, these three potential markers (LPX, GST and GSH) could be used as measure for bio-monitoring the coastal - using mixed zooplankton as suitable organism.

\section{ACKNOWLEDGEMENTS}

The authors are grateful to the Director of National Institute of Oceanography, Goa, for providing the facilities and constant encouragement to carry out the work. Special thanks to Dr. M. S. Shailja, for kindly going through the manuscript and offering valuable suggestions.

\section{REFERENCES}

Bainy AC, Almeida EA, Muller IC, Ventura EC, Medeiros ID (2000). Biochemical response in farmed mussel Perna perna transplanted to contaminated sites on Santa Catarina Island, SC, Brazil. Mar. Environ. Res. 50: 411-416.

Canesi L, Viarengo A, Leonzio C, Filippelli M, Gallo G (1999). Heavy metals and glutathione metabolism in mussel tissues. Aquat. Toxicol. 46: 6776.

De Giulio RT, Benson WH, Sanders BM, Van Veld PA (1995). Biochemical mechanisms: metabolism, adaptation, and toxicity. Fundamentals of Aquatic Toxicology Effects. Environmental Fate and Risk Assessment. pp. 523-556

Edwards R, Dixon DP, Walbot V (2000). Plant glutathione Stransferases: enzymes with multiple functions in sickness and in health. Trends Plant Sci. 5: 193-198.

Elstner EF (1991). Oxygen radicals-biochemical basis for their efficacy. Klin Wochenschr. 69: 949-956.

Fossi MC, Minutoli R, Guglielmo L (2001a). Preliminary Results of Biomarker Responses in Zooplankton of Brackish Environments. Mar. Poll. Bull. 42: 745-748.

Habig WH, Pabst MJ, Jakoby WB (1974). Glutathione S-Transferases. Jour. Biol. Chem. 25: 7130-71.
Halliwell B, Gutteridge JMC (1986). Free Radicals in Biology and Medicine. Oxford:Clarendon Press.

Hammond CL, Madejczyk MS, Ballatori N (2004). Activation of plasma membrane reduced glutathione transport in death receptor apoptosis of HepG2 cells. Toxicol. Appl. Pharmacol. 195: 12-22.

Harding GC (1986). Organochlorine dynamics between zooplankton and their environment, a reassessment. Mar. Ecol. Prog. Ser. 33: 107-19T.

Kanan ST, Sen Gupta R (1987). Organochlorine residues in zooplankton off Saurashtra coast, India. Mar. Poll. Bull. 18: 92-94.

Kureishy TW, George MD, Sen Gupta R (1978). DDT concentration in zooplankton from the Arabian Sea. Ind. J. Mar. Sc. 7: 54-55.

Lau PS, Wong HL (2003). Effect of size, tissue parts and location on six biochemical markers in the green-lipid muscle Perna viridis. Mar. Pullut. 46: 1563-1572.

Lemaire P, Livingstone DR (1994). Aromatic hydrocarbon quinonemediated reactive oxygen species production in hepatic microsomes of the flounder (PlaUchthys flesus $\mathrm{L}$ ).

Lemaire P, Mattheus A, Forlin L, Livingstone DR (1994). Stimulation of oxyradical production microsomes of flounder (PlaUchthys flesus $\mathrm{L}$ ) and Perch (Perca fluviatilis) by model and pollutant xenobiotics. Arch. Environ. Contain. Toxicol. 26: 191-200.

Lenartova V, Holovska K, Pedrajas JL, Martinez-Lara E, Peinado J, Lopez-Barea J, Rosiva I, Kosluth P (1997). Antioxidant and detoxifying fish enzymes as biomarkers of river pollution. Biomarkers, 2: $247-252$

Livingstone DR (2001). Contaminant-stimulated reactive oxygen species production and oxidative damage in aquatic organisms. Mar. Pollut. Bull. 42: 656-666.

Lowry OH, Resebrough NJ, Far AL, Randall RJ (1951). Protein measurement with the Folin phenol reagent. J. Biol. Chem. 193: 265275.

Mannervick B (1985). The isoenzyme of the glutathione S -transferase. Adv. Enzymol. Relat. Areas. Mol. Biol. 57: 357-417.

Oakes KD, Kraak GJVD (2003). Utility of the TBARS assay in detecting oxidative stress in white sucker (Catostomus cmmersoni) populations exposed to pulp mill effluent. Aquat. Toxicol. 63: 447-463.

Ohkawa H, Ohisi N, Yagi K (1979). Assay for lipid peroxides in animal tissues by thiobarbituric acid reaction. Anal. Biochem. 95: 351-358.

Petres LD, Porte C, Livingstone DR (2001). Variation of Antioxidant Enzyme Activity of Spart (Sprattus sprattus) Larvae and Organic Contaminant Levels in mixed zooplankton from the Southern North Sea. Mar. Pollut. Bull. 42: 1087-1095.

Prakash NT, Rao KSJ (1995). Modulations in antioxidant enzymes in different tissues of marine bivalve Perna viridis during heavy metal exposure. Mol. Cell. Biochem. 146: 107-113.

Romero-Isart N, Visak M (2002). Advances in the structure and chemistry of metallothionein. J. Inor. Biochem. 88: 388-396.

Shailaja MS, Nair M (1991). Seasonal Differences in Organochlorine Pesticide Concentrations of Zooplankton and Fish in the Arabian Sea. Mar. Environ. Res. 44: 263-274.

Strmac M, Braunbeck T (2002). Cytological and Biochemical Effects of a Mixture of 20 Pollutants on Isolated Rainbow Trout (Oncorhynchus mykiss) Hepatocytes. Ecotoxicol. Environ. Saf. 53: 293-304.

Torres MA, Testa CP, Gaspari C, Masutti MB, Panitz CMN, CuriPedrosa R, Almeida EA, Mascio PD, Filho DW (2002). Oxidative stress in the mussel Mytella guyanensis from polluted mangroves on Santa Catarina Island, Brazil. Mar. Pollut. Bull. 44: 923-932.

Viarengo A, Canesi A, Pertica M, Poli G, Moore MN, Orunesu M (1990). Heavy metal effects on lipid peroxidation in the tissues of Mytilus galloprovincialis Lam. Comp. Biochem. Physiol. 97: 37-42. 